\title{
The Legal Protection for Journalism of Citizen in the Spread Corona Virus Disease 2019 (COVID-19)
}

\author{
Sitti Aisah Abdullah*, Sabrina Hidayat, Nur Intan
}

Faculty of Law, Halu Oleo University Indonesia

DOI: $\underline{10.36348 / \text { sijlcj.2020.v03i12.002 }}$
*Corresponding author: Sitti Aisah Abdullah

\section{Abstract}

Advances in technology, information and communication make it easy for citizen, especially in Indonesia to find and disseminate information on the spread of Corona Virus Disease 2019 (Covid-19), especially the emergence of the citizen journalism movement that has found a "new life", ordinary people, not journalists, it can create news and distribute it globally. Media company provides oppurtunity to broadcast and publish the news and the information derived from citizen journalism. The existence of citizen journalism has changed the role of the public, which has been the object of news or audience, to become like the professional journalist. Journalistic activity by the citizen journalism in the situation of the spread of the Corona Virus Disease 2019 (Covid-19) pandemic, it must receive legal protection as the guarantee for citizens in spreading truthful information for the public interest.

Keywords: The Legal Protection, The Jurnalism of Citizen, The Spread of Corona Virus Disease 19.

Copyright () 2020 The Author(s): This is an open-access article distributed under the terms of the Creative Commons Attribution 4.0 International License (CC BY-NC 4.0) which permits unrestricted use, distribution, and reproduction in any medium for non-commercial use provided the original author and source are credited.

\section{INTRODUCTION}

The development of advanced information and communication technology today, it has brought the development of journalistic activities to become online journalism or called cyber journalism, which is the new generation of conventional journalism and broadcast journalism. Online journalism is the journalistic activity, covering the process of reporting, writing and disseminating information or news through mass media in the concise and practical manner. In the past, this activity could only be carried out by professional journalist. Now, this activity can be practiced by citizen, not professional journalists. Through online journalism, the public is no longer dependent on the conventional mass media for world information[1]. The development of online journalism has brought important changes in the world of journalism, not only in terms of media and presentation, but also for journalists. The existence of online journalism, especially in the Corona Virus Disease 2019 (Covid-19) situation, everyone can become journalist known as the concept of citizen journalism. Citizen journalism changes the role of the public, which has been the object of news or the audience, to become active like professional journalist. Today, the existence of citizen journalism is able to present the news in factual, objective, accurate, legally, and accountable.
Advances in technology, information and communication have led to journalistic practice of journalism which is carried out by someone who does not have special journalistic expertise as the professional who works in mass media and online media. Mark Glaser said that citizen journalism is a person without professional journalism training, it can use modern technology through the internet platform to create and disseminate information as well as correct news in online media. The advancement of internet technology has given birth to the citizen journalism movement. This means that "new life" has been born where the citizen, not journalists, can make news and distribute it globally. Internet media company has provided space and time to publish news and information. Citizen journalism has also contributed to the development of the new media, namely the emergence of personal blogs and social media which can also like news sites. Terry Flew stated that there are three important elements for the revival of citizen journalism, namely open publishing, collaborative editing and distributed content.

The freedom to convey information through journalistic activity by citizen journalism must still pay attention to aspects of order. Not absolute freedom that violates the privacy of others. The provision of Article 23 paragraph (2) of Law of 39 of 1999 on Human 
Rights is not substantially binding. Protection of human rights is limited because it is the derogable rights. A person who does the crime, it will be punished. The formulation of Article 27 paragraph (1), paragraph (2), paragraph (3) paragraph (4), Article 45, Article 45A, Article 45B of Law of 8 of 2011 on Information and Electronic Transaction, as amended by Law of 19 of 2016 on Amendment to Law of 8 of 2011 on Information and Electronic Transaction of Indonesia. This provision provides the limit for everyone to transmit information on line. Namely, the prohibition of distributing information (news), which contains moral crime, gambling, defamation, extortion and threat, including for citizen journalism. Unfortunately, the Law of 40 of 1999 on the Press of Indonesia, does not guarantee legal protection for citizen journalism in journalistic activity.

Journalistic activity by citizen journalism, in the condition of the Corona Virus Disease 2019 (Covid-19) pandemic, has put the participation of citizen to provide various information through mass media and online media. Determination of the status for health emergency due to the Covid-19 pandemic through the Determination of the Disaster in non-nature of the Covid-19 pandemic, as a national disaster based on the Presidential Decree of Indonesia of 12 of 2020. It has an impact on changes in all sectors, including the information and communication sector. In the Covid-19 pandemic situation, the public needs information, objectivity, accuracy. The journalism information in the distribution of the video about the arrival of 49 foreign workers from China in Southeast Sulawesi, Indonesia, during the Covid-19 condition, the video with a duration of 58 seconds, received massive resistance from the people of Southeast Sulawesi. Moreover, the Indonesia government stated on restriction of travel to other areas.

The presence of citizen journalism has become a competitor to the conventional press, especially the speed of conveying information. The problem with citizen journalism is the accuracy of data and information sources, credibility, and adherence to the journalistic code of ethics. This is because citizen journalism may be wrong in conveying information on the conditions of the corona virus disease 2019 (Covid19). Mistakes include information that contains defamation, fake news, discrimination on religion, race, customs and pornography. The Indonesian Independent Journalists Alliance (AJI), has recognized the existence of citizen journalism as the news contributor. However, AJI is unable to guarantee legal protection for journalistic activities by citizen journalism with the law for Indonesia press. The Indonesia government, at this time, does not have the specific regulation on the protection of citizen journalism in the Indonesia legal system.

\section{METHODOLOGY OF RESEARCH}

This type of writing is the legal research with empirical normative. This research uses primary legal material, which consists of the Constitution of the Republic of Indonesia of 1945, Law of 39 on 1999 on Human Rights, Law of 40 of 1999, Law of 11 of 2008 on Information and Electronic Transactions, as amended by the Law of 19 of 2016 of Amendments to the Law of 11 of 2008 on Information and Electronic Transactions (UUITE), and the Indonesia Criminal Code $(K U H P)$. Secondary legal materials in this study are various references and journals. The analytical approach in this study is the statute approach. This approach is to review all legislations related to this research issue. Also the conceptual approach, used to examine legal views and doctrines related this legal issue [2]. Sources of legal materials are analyzed by the authors to find laws and regulations which provide legal protection for journalism for citizens in the Indonesia legal system, so that laws can be found that can be used in legal protection in journalistic activity by citizen journalism

\section{THE RESULT AND DISCUSSION The Protection of Citizen Journalism in the Indonesia Legal System \\ The essence of citizen journalism protection in} the Indonesia legal system is based on Pancasila as the ideology and philosophy of the Indonesia. It adheres to the principle of the rule of law based on democracy which guarantees freedom of association and expression. Freedom as the manifestation of one of the basic rights of citizen, in exercising rights and freedoms, every citizen is obliged to obey the law as the manifestation of recognition and respect for the rights and freedoms of others. Legal protection, according to Satjipto Raharjo, is the protection of one's interests in the measured manner guaranteed by power[3].

The idea of journalistic activity by citizen journalism in the corona virus disease 2019 (Covid-19) pandemic, citizen will disseminate information, must pay attention to religious values, morality, order, public interests and the integrity of the nation, as regulated in Article 23 Paragraph (2) of the Law of 39 of 1999 on Human Rights. Legal protection of journalistic activity by citizen journalism in Indonesia, adheres to the principles of the rule of law, through recognition and respect for human rights and freedom for others. This provision is regulated in Article 28J Paragraph (1) and Paragraph (2) of the 1945 Constitution of the Republic of Indonesia, that:

1) Every person is obliged to respect the human rights of others in an orderly life in society, nation and state.

2) In exercising rights and freedoms, every person is obliged to submit to the restriction stipulated by the law, solely to guarantee recognition and respect for the rights and 
freedoms of others, and to fulfill fair demands, in accordance with moral and value considerations, the values of religion, security and public order in the democratic society

The formulation of Article 28J paragraph (1) and paragraph (2) of the 1945 Constitution of the Republic of Indonesia confirms that Indonesia is the country of law and democracy, which guarantees freedom to every citizen, including guarantees of rights and freedom in belief, expressing thought and attitude according to conscience and the right to freedom of association to assemble and express opinion as referred to in Article 28E paragraph (2) and paragraph (3) of the 1945 Constitution of the Republic of Indonesia. This freedom is the manifestation of the fulfillment of people's basic right, however, in exercising right and freedom, every citizen is obliged to comply with legal regulation.

If journalistic activity by citizen journalism is prohibited by the State, then the most disadvantaged is not only the State but citizen who is very dependent on mass media and online media in obtaining information for government performance. Since information, everyone can develop themselves by exchanging ideas with fellow citizen about science and knowledge. Article 10 of Law of 30 of 2014 on Government Administration, the state guarantees the participation of every citizen to provide advice to the government. This is in accordance with the general principle of good governance and the principle of protection for human rights.

The criminalization of information and reporting of journalistic activities by citizen journalism through the Criminal Law and the Electronic Information Law, has become the threat to the freedom of citizen in Indonesia. This is against democracy. One of the characteristics of democracy is the freedom of every citizen who must receive legal protection by the government. Legal protection is the guarantee provided as government's responsibility to citizen. Thus, if the freedom of citizen is prohibited, it means violating democracy[4].

According to Paul Scholten, law should not contradict mind and conscience (raison et conscience), the same as Bodin's, that law without justice is like a body without a soul, because the conception of justice is the highest value in the relationship between humans and society. Positivists have the view that justice is indeed the goal of law, but justice closes the elements of legal certainty, such as the adigium of Summun Jus, Summa Injuria: Summa Lex, Summa Crux. Harsh laws can hurt, unless justice helps.

There are four basic principles of human rights, namely freedom, independence, equality and justice. The basic principles of freedom emphasize the freedom of every human being to protect or defend their human rights. The affirmation of the Principles of Freedom of Opinion, Expression and Information, that the right to opinion, the right to freedom of expression, and the right to convey or obtain information are inherent in everyone. However, this principle is only permitted if it meets the following requirements: (1) The restriction is in accordance with the law, (2) restrictions are required in a democratic society, (3) restrictions are made to protect national security (4) The validity of the restrictions becomes the obligation of the government[5].

\section{Citizen Journalism in the Development of Press Law in Indonesia}

During the New Order Era, the role of the government in regulating the life of the Indonesian press had used political will which created the strong press which had bargaining power with the government[6]. However, this condition did not continue in the reform era. The press in the reform era has implemented the freedom of expression of values that is different from the New Order regime. The enactment of the Press Law in Indonesia provides independence on the condition that it has credibility and accountability. The press is considered a part of society whose function cannot be separated as a medium for the transformation of public information. In this system, the press has the responsibility of freedom of the press which guarantees the human rights of citizens and freedom of the press. This means that the national press has the right to seek, obtain and disseminate ideas and information. Guarantee of press freedom is also important to maintain the objectivity and transparency of the press in reporting without fear under government pressure[7].

In the Indonesian legal system, there are no laws and regulations that specifically regulate citizen journalism. The terminology of journalist, freelance journalist and citizen journalism is not stated in the Press Law. This law only uses the terminology of journalists. In this paper, the authors use the terminology of citizen journalism as used by the Press Council and the Big Indonesian Dictionary. The Indonesian Press Law explains that journalistic activities are jobs that are regularly carried out by journalists in carrying out journalistic activities and receive legal protection. Although citizen journalism carries out journalistic activities, if they are not journalists, they do not receive legal protection as journalists. The actions of citizen journalists run the risk of being prosecuted for defamation as stipulated in Article 310 of the Indonesian Criminal Code. On the other hand, according to Article 310 paragraph (3) of the Indonesian Criminal Code, a person's actions are not categorized as defamation if they are committed to defend the public interest or self-defense. Also to reveal the truth. 
Since 2014 the Alliance of Independent Journalists (AJI) has accepted citizen contributors including bloggers as its members and has accepted the existence of citizen journalism, but AJI is unable to guarantee legal protection from journalistic activities by citizen journalism using the Press Law[8]. It states that citizen journalism can become a member of AJI, with the requirements of including 12 journalistic writings which have been published for a year, do not work and activities which are against AJI's Guidelines and AJI's Code of Ethic, it must get recommendation from three AJI members, and not members of political party.

The Council for Indonesia Press views that the presence of citizen journalism reinforces changes in the democratization of information. The collective power of the people increasingly determines the truth of the information disseminated [9]. Publication of information by citizen journalism must comply with the Journalistic Code of Ethic for Indonesian Journalist by presenting news in a balanced and fair, prioritizing accuracy, and not mixing fact and opinion. The writing containing journalist's interpretation and opinion, so that the writer's clear name is included[10].

Citizen journalism usually faces journalistic legal and ethical issues related to the legal regime. Citizen journalism can be practiced by anyone who is not limited by conditions. Thus, citizen journalism can be easily misused. In addition, the speed of information through citizen journalism is very useful, especially during times of crisis, such as natural disasters. Also the view that citizen journalism can interfere with press freedom[11].

Regarding press freedom and responsibility. There are two theories of the press, namely the theory of the press based on liberal principles (libertarian) and the authoritarian press. The liberal press emphasizes aspects of freedom and not in responsibility. The concept of legal responsibility based on this principle is closely related to rights and obligations. Meanwhile, the authoritarian press prioritizes responsibility, but ignores freedom.

In this connection, the press in carrying out journalistic activity must refer to the theory of responsible freedom. Responsible press freedom, according to Oemar Seno Adji, is a press that does not contain insults, incitement, statement that is hostile to religion, pornography and broadcasting fake news. The model of criminal sanction against the press, it is according to criminal law. The presence of citizen journalism is still relevant to the theory of the libertarian press which aims to provide broad information. Citizen journalism encourages the creation of the climate of democratization through freedom of information. Human is virtuous being who is able to distinguish and choose good or wrong. Likewise, social responsibility theory is still relevant to citizen journalism. The press is responsible to the public and provides protection for the public to obtain information widely. Meanwhile, authoritarian theory and communist theory (Soviet/ China) is no relevant to be applied in Indonesia where all publications must be approved by the authorities (government). This means that the government becomes the standard of truth.

Thus, in carrying out its function as the media of information and communication as well as the opinion, it is not merely the reflection of freedom of expression. However, the press is the means of fulfilling human need for dialogue, conveying message (information) to one another through the right of reply and the right of correction. Press freedom in journalistic activities is a form of sovereignty based on the principles of democracy, justice and the rule of law. As the form of press freedom in journalistic activities, the press is guaranteed to seek, obtain and disseminate ideas and information freely. This is the manifestation of the function of the press, namely social control to prevent the abuse of power and against human right violation.

Press freedom in Indonesia today, through the variety of information and mass media. Seems to be increasing[12]. Also, the presence of citizen journalism has brought the variety of information and has become rival for conventional mass media. Looks at the speed of information. However, the challenge of citizen journalism is theccuracy, credibility, and adherence to the journalistic code of ethic. Citizen journalism is not immune from error. Mistakes arise, including defamation, fake news, ethnic content, religion, taste, custom, pornography. The reality of citizen journalism in Indonesia, it is that the government of Indonesia does not yet have the legal basis to provide legal protection for citizen journalism.

\section{CLOSING}

Legal protection of citizen journalism in the legal system of Indonesia is based on Pancasila as the ideology. Freedom of citizen journalism in information, it is not merely free from interference and coercion by any party, but freedom which has moral value and responsibility in social life's Indonesia. Moral values and responsibility come from national value. Although journalistic activity by citizen journalism does not receive legal protection, as in the press law, legal protection for citizen journalism, it should be the responsibility of the Indonesia government. This protection is very necessary to encourage citizen to participate in government. Namely participation in providing information which contains moral value, truth, and the benefit of the Indonesia nation.

\section{REFERENCES}

1. Romli, A. S. M. (2018). Jurnalistik online: Panduan mengelola media online. Nuansa Cendekia. 
2. Marzuki, M. (2017). Penelitian Hukum: Edisi Revisi. Prenada Media.

3. Satjipto, Raharjo, Law Science, Citra Aditya Bakti, Bandung. (1991). 53 quoted in Mahdi Bin Achmad Mahfud and Vinaricha Sucika Wiba, Theory of Law and Implementation of Love, R.A, De. Rozarie, Surabaya, 2015, 82.

4. Handayani, E. P. (2018). Perlindungan Hukum Jurnalisme Warga. DIVERSI: Jurnal Hukum, 2(1), 239-258.

5. Kusumaatmadja, M., \& Sidharta, B. A. (2000). Introduction to Legal Studies A First Introduction to the Scope of Applicability of Law. Bandung: Alumni.

6. Mochtar Lubis, quoted from Wina Armada, Face of Criminal Law of the Press, Pustaka Kartini, Jakarta, 1989, p. 10.

7. Juniver Girsang, Press Dispute Resolution, Gramedia Pustaka Utama, Jakarta, 2007. p. 3.

8. Aryo, S., Faruk, H.T., Budi, I. Focusing on Citizen Journalism: Across History, Conflict of Interest, and Its Relationship with Professional Journalism ", p. 13, http://jurnal.unpad.ac.id/kajian Journalism.

9. https://dewanpers.or.id/berita/detail/452/Jurnalisme -Warga-Dorong-Keberdiversity-Informasi.

10. Muhammad, B. (2016). Journalism Theory and Practice, Youth Rosdakarya, Bandung, 47.

11. Bagir, M. (2013). Journal of the Press Council Edition No. 7, Novemver 2013.

12. Suryopratomo. (2001). Humanism and Press Freedom, Kompas, Jakarta, September, 154

\section{REGULATIONS}

1) 1945 Constitution of the Republic of Indonesia

2) Law of 39 of 1999 concerning Human Rights (State Gazette of the Republic of Indonesia of 1999 Number 165, Supplement to the State Gazette of the Republic of Indonesia Number 3886).

3) Law of 40 of 1999 concerning the Press (State Gazette of the Republic of Indonesia of 1999 Number, Supplement to the State Gazette of the Republic of Indonesia Number 3887).

4) Law of 11 of 2008 concerning Electronic Information and Transactions (State Gazette of the Republic of Indonesia of 2008 of 58, Supplement to the State Gazette of the Republic of Indonesia Number 4843) which has been amended by Law of 19 of 2016 concerning Amendments to Law Number 11 of 2008 concerning Electronic Information and Transactions (State Gazette of the Republic of Indonesia of 2016 Number 251, Supplement to the State Gazette of the Republic of Indonesia Number 5952).

5) Presidential Decree of 11 of 2020 concerning the Determination of the 2019 Corona Virus Disease (Covid-19) Public Health Emergency.

6) Presidential Decree Number 12 of 2020 concerning the Designation of Non-Natural Disaster for the Spread of Corona Virus Disease 2019 (Covid-19) as a National Disaster. 